\title{
Synthesis and evaluation of novel water-soluble ligands for the complexation of metals during the partitioning of actinides $\dagger$
}

\author{
Mudassir Iqbal, ${ }^{a}$ Jurriaan Huskens, ${ }^{a}$ Michal Sypula, ${ }^{b}$ Giuseppe Modolo ${ }^{b}$ and \\ Willem Verboom $* a$
}

Received (in Gainesville, FL, USA) 14th June 2011, Accepted 4th August 2011

DOI: $10.1039 / \mathrm{c} 1 \mathrm{nj} 20523 \mathrm{~d}$

Different types of water-soluble ligands were synthesized and their capability was evaluated by solvent extraction studies to complex trivalent actinides and suppress their extraction by a strong lipophilic ligand, such as TODGA. The back extraction efficiency of hydrophilic diglycolamide (DGA) derivatives with a varying number of ethylene glycol groups, or containing sodium acetate moieties on the amidic nitrogen shows a decrease in back-extraction efficiency with increasing number of ethylene glycol units on the amidic nitrogen at various $\mathrm{pH}$ values of the aqueous phase. Among the $\mathrm{P}=\mathrm{S}$ donating ligands only the ligand with a malonamide backbone exhibits a high reverse extraction efficiency, although, with no selectivity for americium. Within the water-soluble tripodal ligands, i.e. the amide derivatives of nitrilotriacid with $N, N$-dimethyl and $N, N$-bis(hydroxyethyl) moieties, the first one shows a pronounced selectivity for Am(III) over $\mathrm{Eu}(\mathrm{III})$, with a maximum separation factor of 11.1, while the latter one more efficiently complexes the radionuclides in the aqueous phase with a maximum separation factor of 5. Isothermal microcalorimetry experiments of the complexation of Eu(III) by a selected series of ligands confirm the observed trend in the back extraction properties.

\section{Introduction}

The P\&T (Partitioning and Transmutation) strategy aims at decreasing the radiotoxicity of the nuclear waste thereby minimising the cost and the time of its storage. After the recovery of $\mathrm{U}$ and $\mathrm{Pu}$ in the PUREX process (Plutonium Uranium Recovery by Extraction) the main contribution to the total radiotoxicity of the remaining waste is given by the minor actinides ( $\mathrm{Np}, \mathrm{Am}$, and $\mathrm{Cm})$. These elements must be separated from the neutron-absorbing elements such as the lanthanides $(\mathrm{Ln}(\mathrm{III}))$ before being properly transmuted. ${ }^{1}$

A demand exists for the design of new extracting agents for the recovery of An(III). Due to the very similar physicochemical properties of $\mathrm{An}(\mathrm{III})$ and $\mathrm{Ln}(\mathrm{III})$, i.e. trivalent oxidation state in solution, close ionic radii, their partitioning is one of the most challenging issues. ${ }^{2}$

Numerous selective extractants containing nitrogen ${ }^{3}$ or sulfur ${ }^{4}$ functionalities, which are softer than oxygen donors, have been developed to favor An(III) over Ln(III) complexation. ${ }^{5,6}$

\footnotetext{
${ }^{a}$ Laboratory of Molecular Nanofabrication, MESA + Institute for Nanotechnology, University of Twente, P.O. Box 217,

7500 AE Enschede, The Netherlands.E-mail:w.verboom@utwente.nl

${ }^{b}$ Forschungszentrum Juelich $\mathrm{GmbH}$, Institute of Energy and Climate Research-Nuclear Waste Management (IEK-6), 52425 Juelich, Germany

$\dagger$ Electronic supplementary information available: ITC thermograms of Eu(III)-ligand interaction. See DOI: 10.1039/c1nj20523d
}

Within the current European project $\mathrm{ACSEPT}^{7}$ (Actinide reCycling by SEParation and Transmutation) the so-called "innovative SANEX" (Selective ActiNide EXtraction) concept is studied. In this strategy, the trivalent actinides are recovered from the PUREX raffinate by means of one organic solvent, thus reducing the cycles and minimizing the waste. The process consists of an $\mathrm{An}$ (III)/ $\mathrm{Ln}$ (III) co-extraction step at high acidity and then, the loaded solvent is subjected to several stripping steps. The first one concerns selective stripping of trivalent actinides with a selective water-soluble agent followed by the subsequent stripping of trivalent lanthanides.

$N, N, N^{\prime}, N^{\prime}$-Tetraoctyl-3-oxapentanediamide (TODGA) is currently one of the innovative-SANEX reference molecules due to its high distribution ratios for An and Ln from highly acidic media, ${ }^{8}$ high stability in aliphatic diluents, ${ }^{9}$ composition allowing destruction by combustion ( $\mathrm{C}, \mathrm{H}, \mathrm{O}, \mathrm{N}$ principle), and easy synthesis. ${ }^{10}$ Since it shows a slightly higher affinity towards trivalent lanthanides compared to trivalent actinides, the implementation of a selective water-soluble ligand forming stronger complexes with An(III) than Ln(III) would significantly increase the $\mathrm{Ln} / \mathrm{An}$ separation factor. The most well-known hydrophilic ligand EDTA has been studied for the stripping of Am(III) and Cm(III) in the TALSPEAK (Trivalent Actinide Lanthanide Separations by Phosphorus-reagent Extraction from Aqueous Komplexes) process. ${ }^{11,12}$ A number of other carboxylic and polycarboxylic acids have been described by Sasaki et al. ${ }^{13}$ However, EDTA and other carboxylic acids have 
a limited solubility and the solubility also greatly depends on the $\mathrm{HNO}_{3}$ concentration of the aqueous solution. During the stripping process there is always a competition between the organic and the aqueous phase to bind the metals, therefore strong ligands with a high solubility are required to selectively strip the actinide ions. Some water-soluble diglycolamides (tetraalkyl diglycolamide) have been studied by Sasaki et al. ${ }^{13,14}$ however, their water solubility is limited. Water-soluble N-donor ligands, containing pyridine and pyrazine rings described by Heitzmann et al. ${ }^{15,16}$ demonstrate a correlation of the selectivity for trivalent actinides (e.g. Am) over $\mathrm{Ln}$ with the $\mathrm{N}$-donor groups coordinated to the cation (softness of the molecule).

Herein we describe new water-soluble diglycolamides with varying lengths of ethylene glycol chains on the amidic nitrogens, and two novel water-soluble ligands with the backbone similar to diglycolamide ${ }^{10}$ and malonamide, ${ }^{17}$ but with the softer sulfur as a coordinating atom instead of oxygen to study their back-extraction properties.

In a previous study of lipophilic ligands ${ }^{18} 2,2^{\prime}, 2^{\prime \prime}$ nitrilotris $(N, N$-dialkylacetamides) proved to be selective ligands for Am(III), however, only at lower nitric acid concentrations. Since back-extractions of $\mathrm{An}$ (III) and $\mathrm{Ln}$ (III) are performed at low nitric acid concentrations, we also synthesized watersoluble derivatives of these ligands to study their applicability for selective back extraction.

\section{Results and discussion}

\section{Synthesis of water-soluble TODGA derivatives}

The synthesis of water-soluble TODGA derivatives $\mathbf{2}, \mathbf{7} \mathbf{a}, \mathbf{b}$, and $\mathbf{1 0}$ is summarized in Schemes 1 and 2. First diglycolyl dichloride (1) was reacted with diethanolamine in the presence of triethylamine in THF according to a literature procedure. ${ }^{19}$ However, a $1: 1$ mixture was obtained of the desired $2,2^{\prime}$-oxybis $(N, N$-bis $(2-$ hydroxyethyl)acetamide) (2) and the $\mathrm{HCl}$ salt of diethanolamine as followed from ${ }^{1} \mathrm{H}$ NMR spectroscopy, which could not be separated in our hands. ${ }^{20}$ Ligand 2 could be synthesized in $67 \%$ yield by reaction of diglycolyl dichloride (1) with diethanolamine

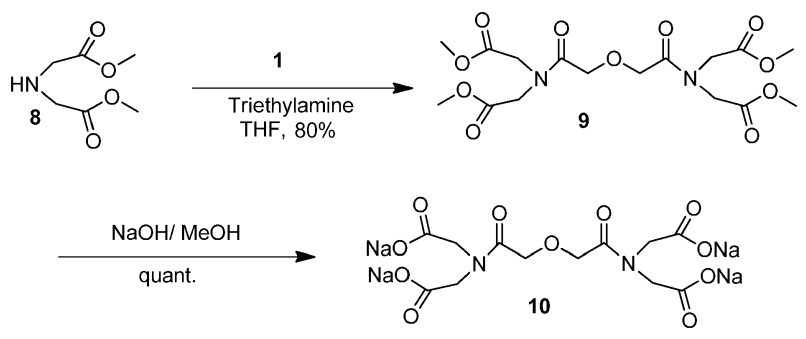

Scheme 2

in acetone using $\mathrm{K}_{2} \mathrm{CO}_{3}$ as a base (Scheme 1). In the ${ }^{1} \mathrm{H}$ NMR spectra the peak for the methylene protons was shifted from $4.57 \mathrm{ppm}$ in $\mathbf{1}$ to $4.28 \mathrm{ppm}$ in $\mathbf{2}$.

To extend the glycol chain in ligand 2 benzylamine (3) was reacted with 2-(2-chloroethoxy)ethanol (4a) and 2-(2-(2-chloroethoxy)ethoxy)ethanol (4b) in the presence of $\mathrm{K}_{2} \mathrm{CO}_{3}$ and $\mathrm{KI}$ in DMF at $110{ }^{\circ} \mathrm{C}$ to give $\mathbf{5 a}^{21}$ and $\mathbf{5 b}$, respectively. Removal of the benzyl group in $\mathbf{5 a}$ and $\mathbf{5 b}$ by hydrogenolysis with $10 \%$ $\mathrm{Pd} / \mathrm{C}$ in methanol afforded $\mathbf{6 a}$ and $\mathbf{6 b}$, which subsequently were reacted with diglycolyl dichloride (1) in acetone to give the desired ligands $7 \mathbf{a}$ and $7 \mathbf{b}$ in $62 \%$ and $63 \%$ yield, respectively (Scheme 1). In the ${ }^{1} \mathrm{H}$ NMR spectra the peak for the methylene protons was shifted from $4.57 \mathrm{ppm}$ in $\mathbf{1}$ to 4.31 and $4.29 \mathrm{ppm}$ in $7 \mathbf{a}$ and $7 \mathbf{b}$, respectively.

The next target molecule was ligand $\mathbf{1 0}$ containing four sodium acetate groups connected to the amidic nitrogen to induce water solubility. Diglycolyl dichloride (1) was reacted with dimethyl 2,2'-azanediyldiacetate $(\mathbf{8})$ in the presence of triethylamine to get tetraester 9 in $80 \%$ yield. Subsequent hydrolysis of the ester groups in 9 using $\mathrm{NaOH}$ in methanol gave $N, N, N^{\prime}, N^{\prime}$-tetrasodium acetate diglycolamide (10) in quantitative yield (Scheme 2). In the ${ }^{1} \mathrm{H}$ NMR spectrum the methyl ester peaks at 3.72 and 3.75 ppm of 9 completely disappeared upon hydrolysis.

\section{Synthesis of S/O-containing ligands}

Water-soluble O-containing ligand with a diglycolamide backbone. (Diethoxyphosphoryl)methyl trifluoromethane-<smiles>CC(C)C[C@H](NCCO)C(C)C</smiles>

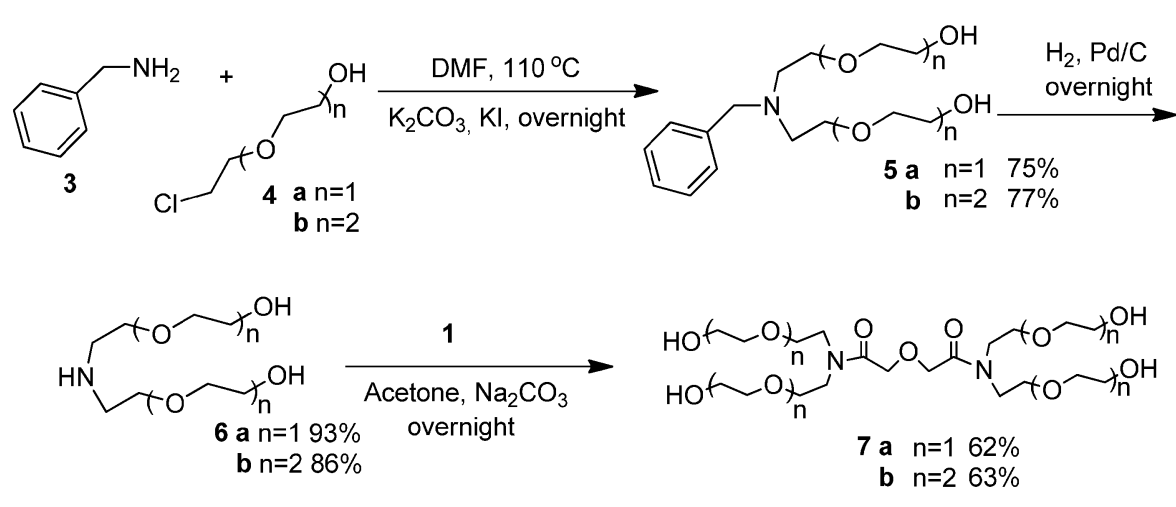

Scheme 1 


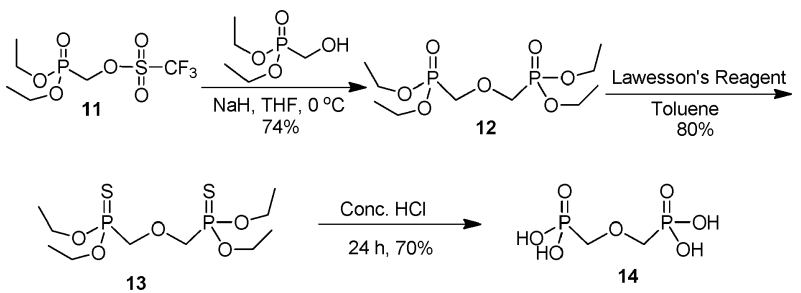

Scheme 3

sulfonate (11), prepared from diethyl(hydroxymethyl)phosphonate according to a literature procedure, ${ }^{22}$ reacted with diethyl(hydroxymethyl)phosphonate in the presence of $\mathrm{NaH}$ as a base to give the desired tetraethyl(oxybis(methylene))bis(phosphonate) (12) in 74\% yield. In the ${ }^{1} \mathrm{H}$ NMR spectra the doublet for the methylene hydrogens at $4.62 \mathrm{ppm}$ in $\mathbf{1 1}$ shifted to $3.85 \mathrm{ppm}$ in $\mathbf{1 2}$. The $\mathrm{P}=\mathrm{O}$ groups in 12 were converted into $\mathrm{P}=\mathrm{S}$ moieties using Lawesson's reagent to afford $\mathbf{1 3}$ in $80 \%$ yield. In this case in the ${ }^{1} \mathrm{H}$ NMR spectrum the methylene protons appeared at $4.10 \mathrm{ppm}$. Subsequent hydrolysis of $\mathbf{1 3}$ with conc. $\mathrm{HCl}$ gave the hydrophilic oxybis(methylene)diphosphonic acid (14) in 70\% yield and not the expected diphosphonothioic acid (Scheme 3). Apparently, during the acid treatment the $\mathrm{P}=\mathrm{S}$ moieties were transformed to $\mathrm{P}=\mathrm{O}$ groups. The ${ }^{1} \mathrm{H}$ NMR spectrum of $\mathbf{1 4}$ shows the methylene protons as a doublet at $3.62 \mathrm{ppm}$. All compounds showed characteristic $M+1$ peaks in their mass spectra. The coupling reaction to give $\mathrm{P}=\mathrm{O}$ ligand $\mathbf{1 2}$ was also performed with a tosylate instead of a triflate group as a leaving group. However, it gave rise to a much lower yield (34\%) of $\mathbf{1 2}$.

S-containing water-soluble ligand with a malonamide backbone. For the synthesis of ligand $\mathbf{1 7}$, with a malonamide backbone, first bis(dichlorophosphino)methane (15) was quantitatively converted into bis(dichlorophosphorothioyl)methane (16) upon treatment with $\mathrm{PSCl}_{3}$ (Scheme 4). In contrast to a literature procedure, $\mathrm{AlCl}_{3}$ was not used as a Lewis acid catalyst. ${ }^{23}$

Subsequently, 16 was reacted with aqueous acetone and complete hydrolysis occurred to give methylenediphosphonothioic $O, O$-acid (17). In the ${ }^{1} \mathrm{H}$ NMR spectra the signal for the methylene hydrogens shifted from $4.48 \mathrm{ppm}$ in $\mathbf{1 6}$ to $2.99 \mathrm{ppm}$ in 17. The electrospray mass spectrum of $\mathbf{1 7}$ exhibited the correct $\mathrm{M}+\mathrm{H}$ peak at $m / z 208.9$.

\section{Synthesis of tripodal ligands}

Different methods were employed for the synthesis of the tripodal ligands 21 and $\mathbf{2 3}$ (Scheme 5). For the synthesis of ligand 21 2-chloro- $N, N$-dimethylacetamide (18) was reacted with benzylamine in acetonitrile to get 19 in $81 \%$ yield. The methylene protons next to chlorine shifted from 4.06 in $\mathbf{1 8}$ to 3.74 ppm in 19 in the ${ }^{1} \mathrm{H}$ NMR spectra. The benzyl group of 19 was cleaved by hydrogenation using $10 \% \mathrm{Pd} / \mathrm{C}$ to give $\mathbf{2 0}$, which was subsequently reacted with $\mathbf{1 8}$ to afford ligand $\mathbf{2 1}$ in $75 \%$ yield. In the ${ }^{1} \mathrm{H}$ NMR spectra the methylene protons

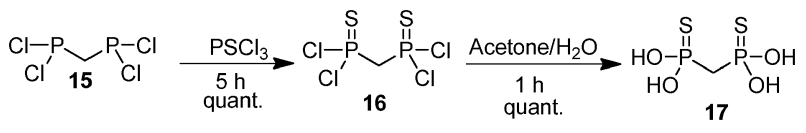

Scheme 4

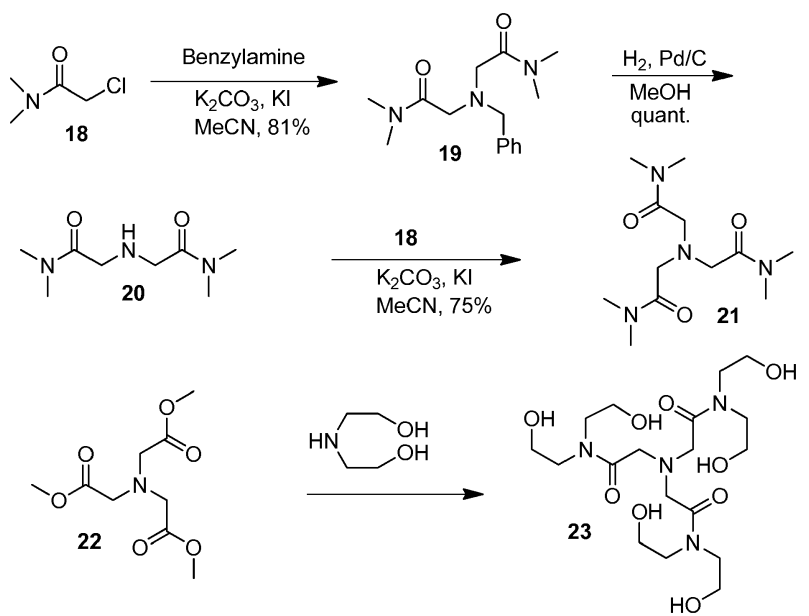

Scheme 5

appeared at $3.62 \mathrm{ppm}$ in $\mathbf{2 1}$. For the synthesis of tripodal ligand $\mathbf{2 3}$ the known triester $\mathbf{2 2}$ was reacted neat with diethanolamine to give the desired ligand 23 in $81 \%$ yield. In the ${ }^{1} \mathrm{H}$ NMR spectrum of $\mathbf{2 3}$ the peak for the methoxy groups in 22 at $3.67 \mathrm{ppm}$ completely disappeared and characteristic triplets for the amidic $\mathrm{CH}_{2}$ protons were found at 3.31 and $3.39 \mathrm{ppm}$.

All these ligands showed infinite solubility in water.

\section{Extraction results}

Preliminary solvent extraction experiments were carried out to determine the back extraction ability of the new water-soluble ligands. An organic solution containing TODGA $+5 \mathrm{vol} \%$ 1-octanol in TPH (Total Petroleum Hydrocarbon/hydrogenated tetrapropene) was used as solvent for the evaluation and comparison of the new ligands.

A certain concentration of the ligand was dissolved in an aqueous $\mathrm{NH}_{4} \mathrm{NO}_{3}\left(0.5 \mathrm{~mol} \mathrm{~L}{ }^{-1}\right)$ solution followed by $\mathrm{pH}$ adjustment and addition of traces of $\mathrm{Am}(\mathrm{III})+\mathrm{Eu}(\mathrm{III})$. The nitrate ion was used as a salting-out agent to compensate the metal charge, since TODGA extracts metals only as neutral species (solvating extraction mechanism). ${ }^{24,25}$ The metal distribution ratio $D_{\mathrm{M}}$ was calculated according to eqn (1) and the percentage of metal ions retained in the water phase after extraction using eqn (2). Therefore, the smaller $D_{M}$ is, the more efficient the back-extraction is.

$$
\begin{aligned}
& D_{\mathrm{M}}=[M]_{\mathrm{org}} /[M]_{\mathrm{aq}} \\
& \% M_{\mathrm{eq}, \mathrm{aq}}=\frac{1}{1+D_{M}} \times 100 \%
\end{aligned}
$$

The separation factor (SF) between $\mathrm{Eu}(\mathrm{III})$ and $\mathrm{Am}$ (III) was calculated using eqn (3).

$$
\mathrm{SF}_{\mathrm{Eu} / \mathrm{Am}}=D_{\mathrm{Eu}} / D_{\mathrm{Am}}
$$

The higher the $\mathrm{SF}_{\mathrm{Eu} / \mathrm{Am}}$ is, the better the selectivity of the water-soluble ligand for Am(III) versus $\mathrm{Eu}(\mathrm{III})$ is.

Water-soluble TODGA derived ligands. The four aliphatic groups of TODGA were substituted by four glycol chains of different lengths in order to increase its hydrophilicity to give the three new highly water-soluble diglycolamide ligands $\mathbf{2}, \mathbf{7 a}$, and $\mathbf{7 b}$. Since they are neutral ligands, it can be anticipated 
that their utility for reverse-extraction experiments in principle is $\mathrm{pH}$ independent. ${ }^{13}$ In contrast, the solubility of (poly)carboxylic acids such as EDTA greatly depends on the $\mathrm{HNO}_{3}$ concentration of the aqueous solution.

Since TODGA shows only a slightly higher affinity for Ln(III) than An(III), no significant separation factor between these two element groups was expected from its hydrophilic derivatives studied in this paper. The distribution ratios of ligand 2 for $\mathrm{Am}$ (III) and $\mathrm{Eu}(\mathrm{III})$ as a function of initial $\mathrm{pH}$ are shown in Fig. 1. The results of our reference extraction system (TODGA) without the presence of the hydrophilic ligand in the aqueous phase are expressed by the dotted lines in Fig. 1 for comparison. It can be seen that high distribution ratios for Am(III) and Eu(III) were obtained and they were not affected by the initial $\mathrm{pH}$ of the aqueous phase due to the salting-out effect of $\mathrm{NO}_{3}{ }^{-}$. The $D$-values for Am were between 34 and 76, whereas higher $D$-values (250-323) were obtained for $\mathrm{Eu}$, resulting in separation factors $\mathrm{SF}_{\mathrm{Eu} / \mathrm{Am}}$ between 4.5 and 7.2.

Ligand 2 with the shortest glycol chain at the $N$-amide of the DGA showed a very strong complexation for ${ }^{241} \mathrm{Am}+{ }^{152} \mathrm{Eu}$ with increasing ligand concentration. At a fixed ligand concentration of $0.1 \mathrm{~mol} \mathrm{~L}^{-1}$, the extraction of $\mathrm{Am}$ (III) and $\mathrm{Eu}(\mathrm{III})$ was progressively more suppressed with increasing $\mathrm{pH}$ of the aqueous solution (Fig. 1). Even at $\mathrm{pH}_{\mathrm{ini}}=1$ the distribution ratios $D_{\mathrm{Am}}$ and $D_{\mathrm{Eu}}$ were 0.2 and 0.5 , respectively $\left(D_{\mathrm{M}}\right.$ less than 1 expresses that $>50 \%$ of the metal is retained in the aqueous phase). As expected, no significant separation between $\mathrm{Eu}(\mathrm{III})$ and $\mathrm{Am}(\mathrm{III})$ was observed $\left(\mathrm{SF}_{\mathrm{Eu} / \mathrm{Am}}<2\right)$. Moreover, the discrimination between both radionuclides decreased further with increasing $\mathrm{pH}_{\mathrm{ini}}$ (Table 1). Decreasing the ligand 2 concentration below $0.1 \mathrm{~mol} \mathrm{~L}^{-1}$ decreased the metals complexation in the aqueous phase and thus increased the extraction of $\mathrm{Am}(\mathrm{III})$ and Eu(III) into the organic phase (Fig. 1). Only at $\mathrm{pH}=4$ and a low concentration of $0.01 \mathrm{~mol} \mathrm{~L}^{-1}$ ligand 2 it was sufficient to keep most of Am(III) and $\mathrm{Eu}(\mathrm{III})$ in the aqueous phase. A lower initial $\mathrm{pH}$ resulted in $D$-values more than $1(<50 \%$ metal kept in the aqueous phase).

The extraction kinetics of Am(III) and Eu(III) by $0.1 \mathrm{~mol} \mathrm{~L}^{-1}$ ligand 2 at $\mathrm{pH} 3$ with formation of aqueous Am- and Eu-ligand 2 complexes is very fast. Only a mixing time of 5 minutes was required to suppress the $\mathrm{Am}+\mathrm{Eu}$ extraction by TODGA (Fig. S1, ESI $\dagger$ ). The equilibrium values reached after 5 minutes did not further change up to 60 minutes mixing time, indicating the formation of strong and stable metal complexes.

Compared to ligand $\mathbf{2}$, the chains of ligands $\mathbf{7 a}$ and $\mathbf{7 b}$ contain one and two more ethylene glycol units, increasing the hydrophilicity. Both new water-soluble DGA ligands 7a and $\mathbf{7 b}$ do not complex Am(III) and Eu(III) as effectively as ligand 2 (Fig. 2). Only at $\mathrm{pH}_{\text {ini }}=4$ ligand $7 \mathbf{a}$ kept most of the radionuclides in the aqueous phase $\left(D_{\mathrm{Am}}=0.5\right.$ and $\left.D_{\mathrm{Eu}}=0.92\right)$.

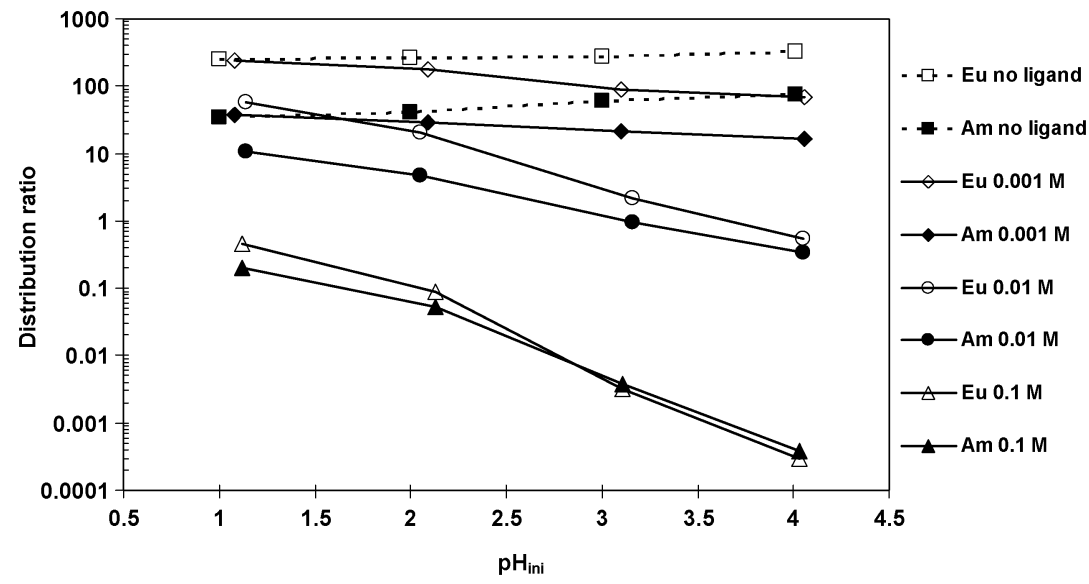

Fig. 1 Initial $\mathrm{pH}_{\mathrm{aq}}$ and ligand (2) concentration dependency for the extraction of ${ }^{241} \mathrm{Am}$ and ${ }^{152}$ Eu. Organic phase: 0.2 mol L ${ }^{-1}$ TODGA + $5 \mathrm{vol} \%$ 1-octanol in TPH. Aqueous phase: $0.5 \mathrm{~mol} \mathrm{~L}{ }^{-1} \mathrm{NH}_{4} \mathrm{NO}_{3}$, variable $\mathrm{pH}_{\text {ini }}$, variable concentrations of ligand 2, tracers: ${ }^{241} \mathrm{Am},{ }^{152} \mathrm{Eu}$, mixing time: $60 \mathrm{~min} ; T=22{ }^{\circ} \mathrm{C} \pm 1{ }^{\circ} \mathrm{C}$.

Table 1 Percentages of retained ions in the aqueous phase and Eu/Am separation factors using ligands $\mathbf{2}$ and $\mathbf{1 7}$

\begin{tabular}{|c|c|c|c|c|c|c|c|}
\hline \multirow[b]{2}{*}{ Ligand conc. $/ \mathrm{mol} \mathrm{L}^{-1}$} & \multirow[b]{2}{*}{$\mathrm{pH}_{\text {ini }}$} & \multicolumn{3}{|l|}{ Ligand 2} & \multicolumn{3}{|l|}{ Ligand 17} \\
\hline & & $\% \mathrm{Am}_{\mathrm{aq}, \mathrm{eq}}$ & $\% \mathrm{Eu}_{\mathrm{aq}, \mathrm{eq}}$ & $\mathrm{SF}_{\mathrm{Eu} / \mathrm{Am}}$ & $\% \mathrm{Am}_{\mathrm{aq}, \mathrm{eq}}$ & $\% \mathrm{Eu}_{\mathrm{aq}, \mathrm{eq}}$ & $\mathrm{SF}_{\mathrm{Eu} / \mathrm{Am}}$ \\
\hline \multirow[t]{4}{*}{0} & 1 & 2.83 & 0.40 & 7.2 & 2.83 & 0.40 & 7.2 \\
\hline & 2 & 2.38 & 0.39 & 6.3 & 2.38 & 0.39 & 6.3 \\
\hline & 3 & 1.64 & 0.37 & 4.5 & 1.64 & 0.37 & 4.5 \\
\hline & 4 & 1.31 & 0.31 & 4.3 & 1.31 & 0.31 & 4.3 \\
\hline \multirow[t]{4}{*}{0.1} & 1 & 83.45 & 68.78 & 2.3 & 95.16 & 90.70 & 2.0 \\
\hline & 2 & 95.01 & 91.78 & 1.7 & 99.42 & 99.47 & 0.9 \\
\hline & 3 & 99.63 & 99.68 & 0.9 & 99.75 & 99.73 & 1.0 \\
\hline & 4 & 99.96 & 99.97 & 0.7 & 99.74 & 99.78 & 0.8 \\
\hline
\end{tabular}




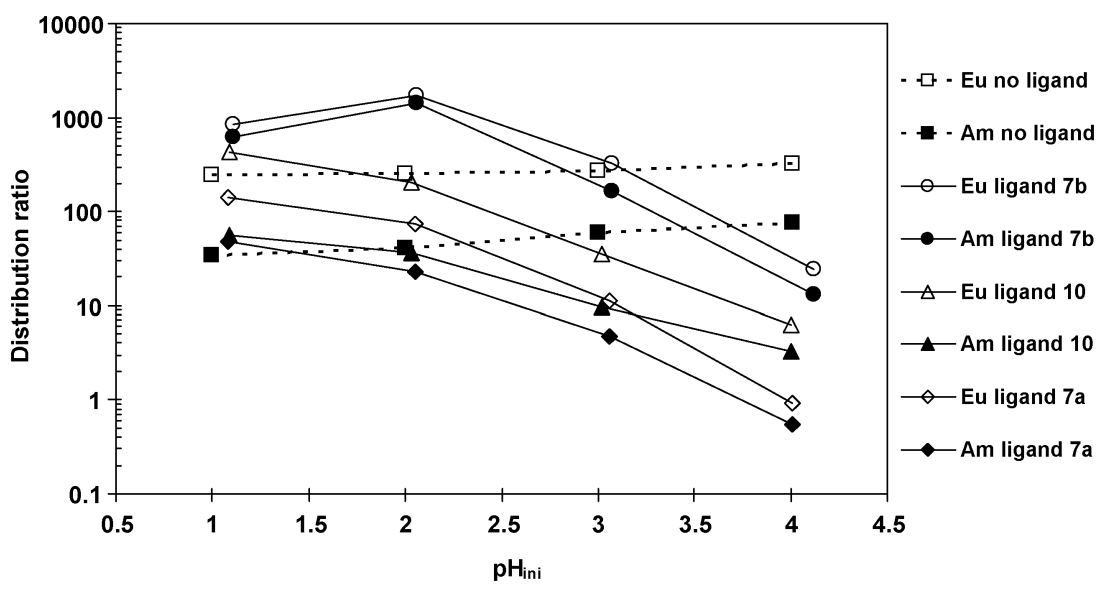

Fig. 2 Initial $\mathrm{pH}_{\mathrm{aq}}$ dependency for the extraction of ${ }^{241} \mathrm{Am}$ and ${ }^{152} \mathrm{Eu}$. Organic phase: $0.2 \mathrm{~mol} \mathrm{~L}{ }^{-1}$ TODGA +5 vol\% 1 -octanol in TPH. Aqueous phase: $0.5 \mathrm{~mol} \mathrm{~L}^{-1} \mathrm{NH}_{4} \mathrm{NO}_{3}$, variable $\mathrm{pH}_{\text {ini }}, 0.1 \mathrm{~mol} \mathrm{~L}^{-1}$ ligand $\mathbf{7 a}, \mathbf{7 b}\left(0.01 \mathrm{~mol} \mathrm{~L}{ }^{-1}\right.$ ligand 10), tracers: ${ }^{241} \mathrm{Am},{ }^{152} \mathrm{Eu}$, mixing time: $60 \mathrm{~min} ; T=22{ }^{\circ} \mathrm{C} \pm 1{ }^{\circ} \mathrm{C}$.

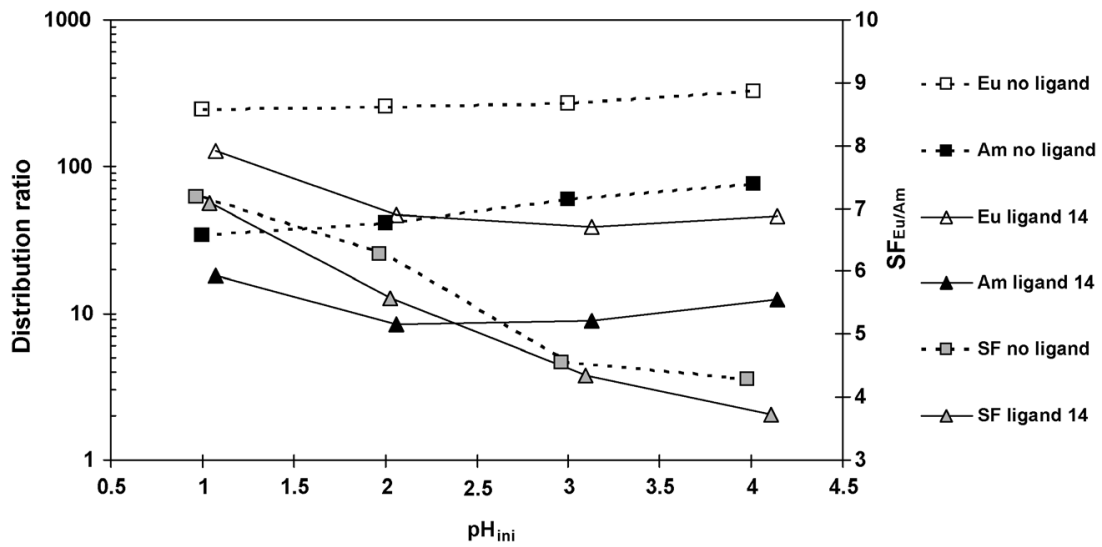

Fig. 3 Initial $\mathrm{pH}_{\mathrm{aq}}$ dependency for the extraction of ${ }^{241} \mathrm{Am}$ and ${ }^{152} \mathrm{Eu}$. Organic phase: $0.2 \mathrm{~mol} \mathrm{~L}{ }^{-1}$ TODGA +5 vol\% 1 -octanol in TPH. Aqueous phase: $0.5 \mathrm{~mol} \mathrm{~L}^{-1} \mathrm{NH}_{4} \mathrm{NO}_{3}$, variable $\mathrm{pH}_{\text {ini }}$, ligand $\mathbf{1 4}<0.03 \mathrm{~mol} \mathrm{~L}-1$, tracers: ${ }^{241} \mathrm{Am},{ }^{152} \mathrm{Eu}$, mixing time: $60 \mathrm{~min} ; T=22{ }^{\circ} \mathrm{C} \pm 1{ }^{\circ} \mathrm{C}$.

Surprisingly, higher distribution ratios were observed for ligand $\mathbf{7 b}$ in comparison with the TODGA reference extraction system (dotted lines) at $\mathrm{pH}<2$. At $\mathrm{pH} 3$ they are comparable and only at $\mathrm{pH} 4$, they are lower than in the absence of the ligand.

Finally, water-soluble diglycolamide derivative $\mathbf{1 0}$ was tested in which the aliphatic chains connected to the amidic nitrogen of the parent TODGA are substituted by four sodium acetate groups. The solubility of this ligand was poorer than that of the three ligands with glycol chains and a clear solution was obtained at a ligand concentration of $0.01 \mathrm{~mol} \mathrm{~L}^{-1}$ in the aqueous phase. The distribution ratios $D_{\mathrm{Am}}$ and $D_{\mathrm{Eu}}$ decreased with increasing $\mathrm{pH}_{\text {ini }}$. However, the complexes formed were not strong enough to prevent the metals extraction (Fig. 2) by TODGA.

Ligand 14, with a diglycolamide backbone, has a poor solubility in $0.5 \mathrm{~mol} \mathrm{~L}^{-1} \mathrm{NH}_{4} \mathrm{NO}_{3}$ solution. After adjusting the ligand concentration to $0.03 \mathrm{~mol} \mathrm{~L}^{-1}$, still small un-dissolved residues were visible in the solution. After centrifugation, the clear supernatant was used for the subsequent extraction experiment (see Fig. 3). The distribution ratios of $\mathrm{Am}$ and $\mathrm{Eu}$ do not significantly decrease with increasing $\mathrm{pH}_{\text {ini. }}$. There is only a drop between $\mathrm{pH}_{\text {ini }}=1$ and 2 . In the initial $\mathrm{pH}$ range of 2-4 the $D_{\mathrm{Am}}$ and $D_{\mathrm{Eu}}$ values remain nearly constant around 10 and 40, respectively, indicating only poor complexation properties for reverse extraction. In addition, no increased complexation for the trivalent Am(III) was observed in comparison to the extraction system without the ligand, since the curves for $\mathrm{Eu} / \mathrm{Am}$ are nearly overlapping one another.

Sulfur containing ligands. In order to increase the selectivity for the trivalent actinides over the lanthanides two hydrophilic ligands containing sulfur bearing groups were synthesised to study the impact of S-donors on their complexation properties. Sulfur containing ligand $\mathbf{1 7}$, having a malonamide backbone, has a good solubility and allowed the preparation of a $0.1 \mathrm{~mol} \mathrm{~L}^{-1}$ solution. At this high ligand concentration, both Am(III) and Eu(III) were strongly complexed in the aqueous phase in the entire $\mathrm{pH}_{\text {ini }}$ range studied, thus their extraction by TODGA was significantly prevented (Fig. 4). Over $90 \%$ of each metal stayed in the aqueous phase at $\mathrm{pH}_{\mathrm{ini}}=1$, while over $99 \%$ at $\mathrm{pH}_{\text {ini }}=2-4$ (Table 1$)$.

Decreasing the ligand 19 concentration, the distribution ratios of Am(III) and Eu(III) increased, although in comparison with ligand 2 ( $c f$. Fig. 1), the S-containing ligand seems to form more stable complexes, especially at lower $\mathrm{pH}_{\mathrm{ini}}$. 


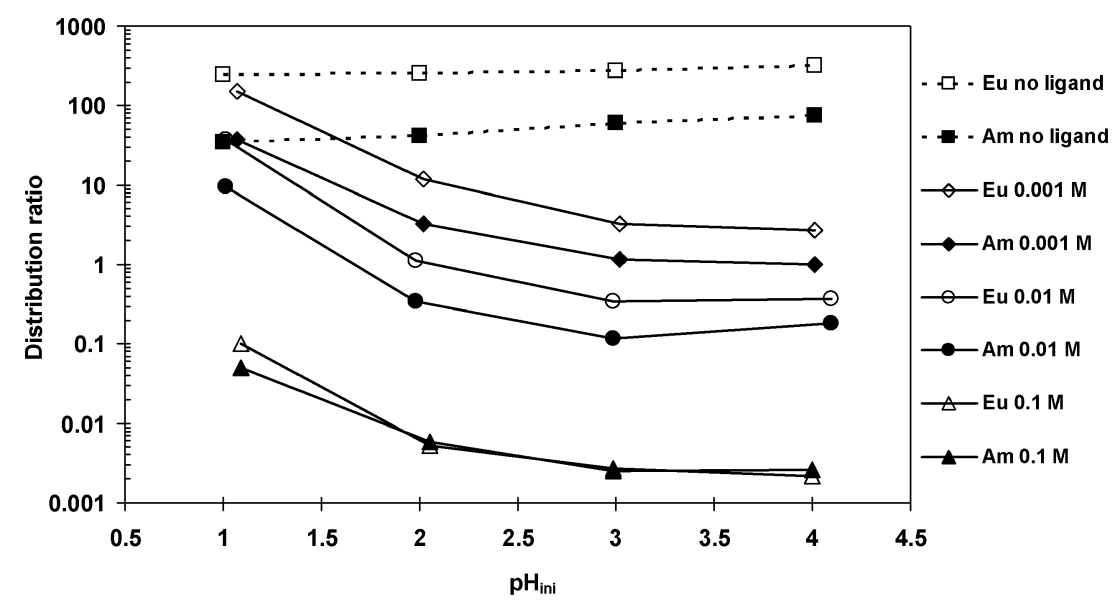

Fig. 4 Initial $\mathrm{pH}_{\mathrm{aq}}$ and ligand 17 concentration dependency for the extraction of ${ }^{241} \mathrm{Am}$ and ${ }^{152} \mathrm{Eu}$. Organic phase: $0.2 \mathrm{~mol} \mathrm{~L}{ }^{-1}$ TODGA + 5 vol\% 1-octanol in TPH. Aqueous phase: $0.5 \mathrm{~mol} \mathrm{~L}{ }^{-1} \mathrm{NH}_{4} \mathrm{NO}_{3}$, variable $\mathrm{pH}_{\mathrm{ini}}$, variable concentration of ligand (17), tracers: ${ }^{241} \mathrm{Am},{ }^{152} \mathrm{Eu}$, mixing time: $60 \mathrm{~min} ; T=22{ }^{\circ} \mathrm{C} \pm 1{ }^{\circ} \mathrm{C}$.

The separation factor $\mathrm{SF}_{\mathrm{Eu} / \mathrm{Am}}$ decreased from 2.0 to 0.8 with increasing $\mathrm{pH}_{\text {ini }}$ (Table 1).

Ligand 17 exhibits a fast complexation kinetics and distribution ratios close to the equilibrium value are reached within 5 minutes of mixing time (Fig. S2, ESI $\dagger$ ). Longer mixing times up to 60 minutes did not show any change, indicating the formation of strong and stable metal complexes.

Tripodal ligands. The extraction results for the new tripodal ligands 21 and 23 are shown in Fig. 6 and 7, respectively. The $\mathrm{SF}_{\mathrm{Eu} / \mathrm{Am}}$ for ligand $\mathbf{2 1}$ decreases upon raising the $\mathrm{pH}_{\mathrm{ini}}$ of the aqueous phase. However, a higher selectivity for Eu(III) over Am(III) was obtained at a $\mathrm{pH}_{\text {ini }}$ range of $1-3$ compared to the $\mathrm{SF}_{\mathrm{Eu} / \mathrm{Am}}$ of the TODGA system without ligand (dotted line in Fig. 6). The $\mathrm{SF}_{\mathrm{Eu} / \mathrm{Am}}=11.1$ (ligand 21 at $\mathrm{pH}_{\mathrm{ini}}=2$ ) is comparable with the $\mathrm{SF}_{\mathrm{Am} / \mathrm{Eu}}=11.8$ obtained for the lipophilic ligand 2,2 $2^{\prime \prime}$-nitrilotris( $N, N$-bis(2-ethylhexyl)acetamide) (24; see Fig. 5) at $\left[\mathrm{HNO}_{3}\right]=0.01 \mathrm{~mol} \mathrm{~L}^{-1} \cdot{ }^{18} \mathrm{At}$ these conditions $72 \%$ of ${ }^{241} \mathrm{Am}$ and only $19 \%$ of ${ }^{152} \mathrm{Eu}$ remained in the aqueous phase. Over 98 and 92 percent of radionuclides were not extracted by TODGA at the highest tested $\mathrm{pH}_{\text {ini }}=4\left({ }^{241} \mathrm{Am}\right.$ and ${ }^{152} \mathrm{Eu}$, respectively).

The results of the tripodal ligand $\mathbf{2 3}$ reveal a similar complexing behavior as ligand 21. Increase of the initial $\mathrm{pH}$ of the aqueous phase increased the metals complexation (Fig. 7), however, low distribution ratios indicate that more metals retained in the aqueous phase compared to ligand $\mathbf{2 1}$ for $\mathrm{pH}_{\mathrm{ini}}=3$ and 4 . This can be partly explained by the different concentrations of the two ligands, resulting from a poorer solubility of ligand $\mathbf{2 1}$.

The Eu/Am separation factors were almost the same as those of TODGA in the absence of the ligand. As a matter of fact the $\mathrm{SF}_{\mathrm{Eu} / \mathrm{Am}}$ at $\mathrm{pH}_{\mathrm{ini}}=1$ and 2 is even lower than in the reference experiment (dotted line). In conclusion, ligand $\mathbf{2 1}$ shows a good discrimination for Am(III), while ligand $\mathbf{2 3}$ is more efficient in stripping of Am(III) and Eu(III) simultaneously.

\section{Microcalorimetry}

Isothermal microcalorimetry (ITC) experiments were performed to study the difference in the binding strengths of<smiles>[Z4]CCC(CC)CN(CC(CCC)CCC)C(=O)CN(CC(=O)N(CC(CC)CCC)CC(CC)CCCC)CC(=O)N(CC(CC)CCCC)CC(CCC)CCCC</smiles>

Fig. 5 Structure of $2,2^{\prime}, 2^{\prime \prime}$-nitrilotris( $N, N$-bis(2-ethylhexyl)acetamide).

ligands $\mathbf{2}, \mathbf{7 a}, \mathbf{b}, \mathbf{2 1}$, and $\mathbf{2 3}$ towards $\mathrm{Eu}(\mathrm{III})$ in water at $\mathrm{pH} 3$. The binding constants and the thermodynamic data are summarized in Table 2. Dilution experiments with ligands 2 , $\mathbf{7 a , b}, 21$ showed negligible heat effects indicating that no aggregation of the ligands takes place under the conditions used. For ligand $\mathbf{2 3}$ some dilution effect was observed, however, correcting the $\Delta H$ complexation values for it, no significant change was observed in the $\Delta H$ versus molar ratio plot (see ESI $\dagger$ ).

From Table 2 it is clear that ligands $\mathbf{2}, \mathbf{7 a}$, and $\mathbf{7 b}$ show a complexation affinity towards Eu(III) in the order $\mathbf{2}>\mathbf{7 a}>\mathbf{7 b}$. The stripping efficiency in the back extraction experiments described above can be explained by the binding efficiency of the different ligands towards Eu(III). Ligand $\mathbf{2}$ is the most efficient ligand as follows from both the extraction results as well as the ITC experiments. Ligand $\mathbf{2}$ shows an already sufficiently good fit for 2:1 (ligand:metal) complexation, however, ligands $\mathbf{7 a}$ and $\mathbf{7 b}$ show an already sufficiently good fit for a $1: 1$ stoichiometry, probably due to the lower affinity observed for these ligands. More importantly and noticeably, the $1: 1$ complex of ligand 2 shows a relatively low binding enthalpy compared to ligands $\mathbf{7 a}$ and $\mathbf{7 b}$, which is fully compensated by a strongly positive entropy of binding for ligand 2. This is attributed partially to co-coordination of the hydroxyl groups of ligand $\mathbf{2}$ to the Eu center (associated with a negative enthalpy and a positive entropy of complexation 


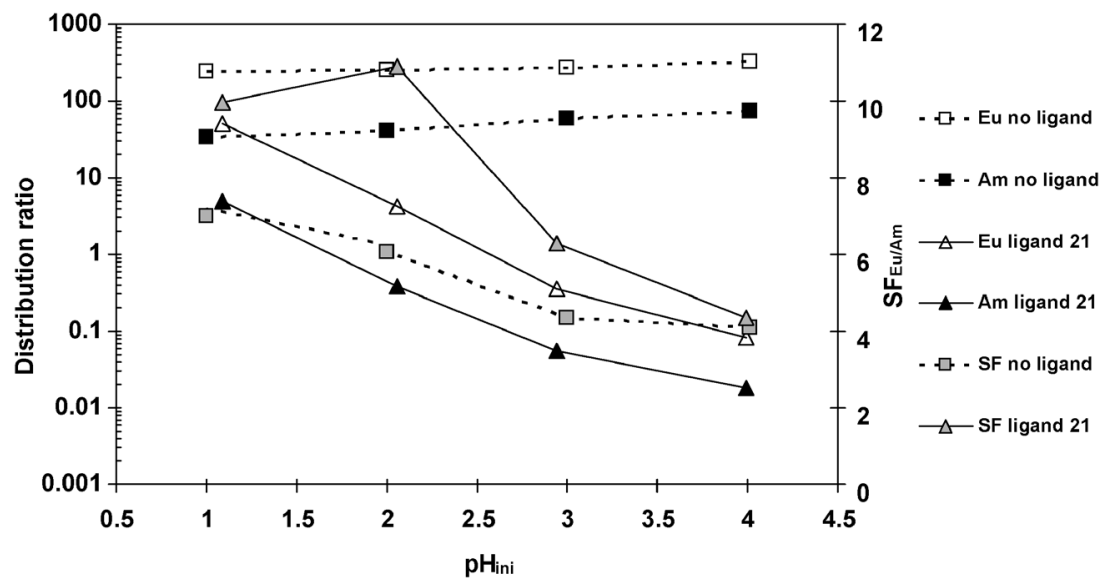

Fig. 6 Initial $\mathrm{pH}_{\mathrm{aq}}$ dependency for the extraction of ${ }^{241} \mathrm{Am}$ and ${ }^{152} \mathrm{Eu}$. Organic phase: $0.2 \mathrm{~mol} \mathrm{~L}{ }^{-1} \mathrm{TODGA}+5 \mathrm{vol} \% 1-\mathrm{octanol}$ in $\mathrm{TPH}$. Aqueous phase: $0.5 \mathrm{~mol} \mathrm{~L}^{-1} \mathrm{NH}_{4} \mathrm{NO}_{3}$, variable $\mathrm{pH}_{\text {ini }}, 0.07 \mathrm{~mol} \mathrm{~L}{ }^{-1}$ ligand 21 , tracers: ${ }^{241} \mathrm{Am},{ }^{152} \mathrm{Eu}$, mixing time: $60 \mathrm{~min} ; T^{\circ}=22{ }^{\circ} \mathrm{C} \pm 1{ }^{\circ} \mathrm{C}$.

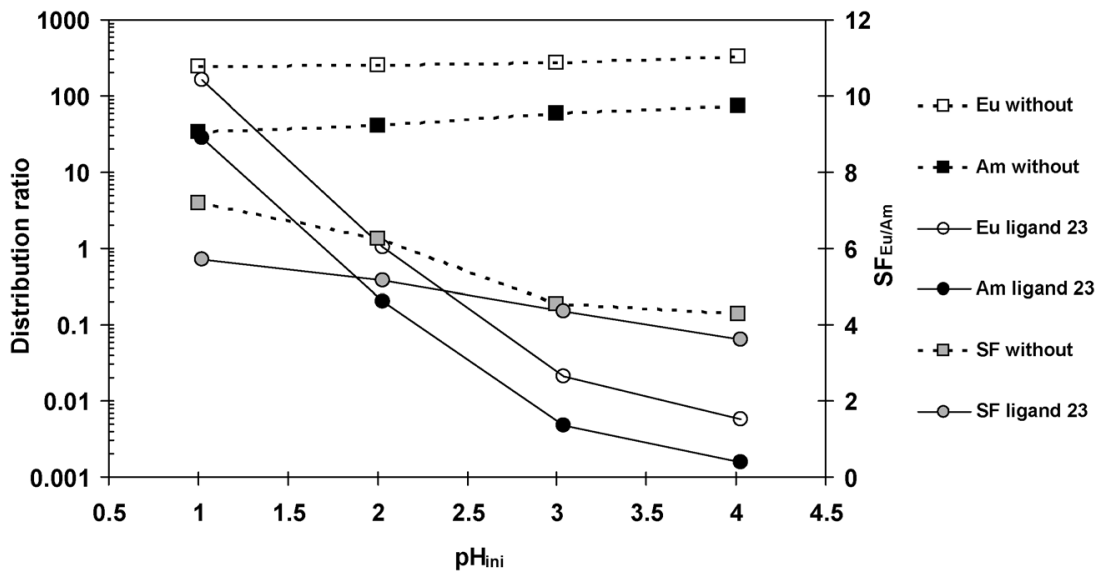

Fig. 7 Initial $\mathrm{pH}_{\mathrm{aq}}$ dependency for the extraction of ${ }^{241} \mathrm{Am}$ and ${ }^{152} \mathrm{Eu}$. Organic phase: $0.2 \mathrm{~mol} \mathrm{~L}{ }^{-1} \mathrm{TODGA}+5 \mathrm{vol} \%$ 1-octanol in TPH. Aqueous phase: $0.5 \mathrm{~mol} \mathrm{~L}^{-1} \mathrm{NH}_{4} \mathrm{NO}_{3}$, variable $\mathrm{pH}_{\text {ini }}, 0.1 \mathrm{~mol} \mathrm{~L}-1$ ligand 23, tracers: ${ }^{241} \mathrm{Am},{ }^{152} \mathrm{Eu}$, mixing time: $60 \mathrm{~min} ; T=22{ }^{\circ} \mathrm{C} \pm 1{ }^{\circ} \mathrm{C}$.

Table 2 Binding constants and thermodynamic parameters of the binding of ligands $\mathbf{2}, \mathbf{7 a}, \mathbf{7 b}, \mathbf{2 1}$, and $\mathbf{2 3}$ with $\mathrm{Eu}(\mathrm{III})$ determined with microcalorimetry in water at $25^{\circ} \mathrm{C}^{a}$

\begin{tabular}{llllc}
\hline Ligand & $K / \mathrm{mol}^{-1}$ & $\Delta G / \mathrm{kcal} \mathrm{mol}^{-1}$ & $\Delta H / \mathrm{kcal} \mathrm{mol}^{-1}$ & $T \Delta S / \mathrm{kcal} \mathrm{mol}^{-1}$ \\
\hline $\mathbf{2}^{b}$ & $6.4 \times 10^{5}$ & $-7.3 \pm 0.7$ & $-1.0 \pm 0.1$ & $6.3 \pm 0.8$ \\
& $7.3 \times 10^{3}$ & $-4.9 \pm 0.4$ & $-4.0 \pm 0.1$ & $0.9 \pm 0.5$ \\
$\mathbf{7 a}$ & $2.2 \times 10^{3}$ & $-4.3 \pm 0.3$ & $-3.6 \pm 0.4$ & $0.7 \pm 0.7$ \\
$\mathbf{7 b}$ & $7.1 \times 10^{2}$ & $-3.9 \pm 0.1$ & $-4.1 \pm 0.2$ & $-0.2 \pm 0.4$ \\
$\mathbf{2 1}^{b}$ & $1.4 \times 10^{3}$ & $-4.2 \pm 0.1$ & $4.2 \pm 0.1$ & $8.4 \pm 0.3$ \\
& $3.5 \times 10^{2}$ & $-3.4 \pm 0.1$ & $3.9 \pm 0.1$ & $7.3 \pm 0.2$ \\
$\mathbf{2 3}$ & $1.5 \times 10^{4}$ & $-5.5 \pm 0.2$ & $3.6 \pm 0.3$ & $9.1 \pm 0.5$
\end{tabular}

${ }^{a}$ Ligand conc. $=10 \mathrm{mmol} \mathrm{L}{ }^{11}, \mathrm{Eu}(\mathrm{III})$ conc. $=0.166 \mathrm{mmol} \mathrm{L}^{\neg 1}$. ${ }^{b}$ Ligands 2 and 21 show the best fit for $2: 1(\mathrm{~L}: \mathrm{M})$ complexation, so the thermodynamic parameters are given for both the $1: 1$ (first row) and $2: 1$ (second row) complexes.

owing to release of first coordination sphere water molecules) and partially to more negative entropies of binding for ligands $\mathbf{7 a}$ and $\mathbf{7 b}$ due to restricted degrees of conformational freedom of the ethylene glycol chains upon complexation. Ligand $\mathbf{7 b}$ has a lower $K$-value than ligand $\mathbf{7 a}$, which apparently is not high enough for back extraction (vide supra). The longer glycol chains on the amidic nitrogens in $\mathbf{7 b}$ compared to $\mathbf{7 a}$ weaken the binding capacity of the ligand. A similar effect was observed by Rao et al. ${ }^{26}$ for malonamide ligands by changing the substituents on the amidic nitrogen in acetonitrile. The ITC experiments performed here indicate that the poorer performance of ligand $\mathbf{7 b}$ is due to a more negative entropy effect of binding for ligand $\mathbf{7 b}$ compared to $\mathbf{7 a}$.

The tripodal ligands $\mathbf{2 1}$ and $\mathbf{2 3}$ show the best fit for 2: 1 and $1: 1$ (ligand:metal) complexation, respectively, in an endothermic process. ${ }^{27}$ Ligand $\mathbf{2 3}$ has a stronger binding affinity for Eu(III) than ligand $\mathbf{2 1}$ as clearly corresponds with the back extraction data (vide supra). The ITC data indicate that ligand 21 binds Eu in a 2:1 fashion, which is logical because of its tetradentate nature. The facts that ligand $\mathbf{2 3}$ binds stronger but only shows a $1: 1$ stoichiometry indicate that in this case several of the ethylene glycol moieties are involved in binding. This is also witnessed by the more endothermic enthalpy of binding and more positive entropy of binding, both in agreement with a higher loss of water from the first coordination sphere.

\section{Conclusion}

Different types of water-soluble ligands, partly based on the well-known TODGA and malonamide skeletons, have successfully been prepared. In most cases they show very good 
back extraction properties of $\mathrm{Am}$ (III) and $\mathrm{Eu}(\mathrm{III})$ from a TODGA-containing organic phase, dependent on the $\mathrm{pH}$, however, without selectivity. However, only water-soluble tripodal ligands 21 and 23 exhibit a promising $\mathrm{SF}_{\mathrm{Eu} / \mathrm{Am}}$ of 11.1 and 5, respectively. It is clearly demonstrated that microcalorimetry is an efficient method to determine the (trend in the) extraction efficiency of different ligands.

\section{Experimental}

\section{General}

All moisture-sensitive reactions were carried out under an argon atmosphere. The solvents and all reagents were obtained from commercial sources and used without further purification. All known compounds viz. $\mathbf{1}^{28} \mathbf{1 1},{ }^{22} \mathbf{1 8},{ }^{29}$ and $\mathbf{2 2}^{30}$ were prepared according to literature procedures. Solvents were dried according to standard procedures and stored over molecular sieves. ${ }^{1} \mathrm{H}$ NMR and ${ }^{13} \mathrm{C}$ NMR spectra were recorded on a Varian Unity INOVA (300 MHz) spectrometer. ${ }^{1} \mathrm{H}$ NMR (300 MHz) and ${ }^{13} \mathrm{C}$ NMR (75 MHz) chemical shift values are reported as $\delta$ using the residual solvent signal as an internal standard. The IR spectrum was recorded on a Perkin Elmer Spectrum BX2 spectrometer. Electrospray Ionization (positive mode) mass spectra and high resolution mass spectra were recorded on a WATERS LCT mass spectrometer. Elemental analyses were performed using a Flash 200 $\mathrm{CHN}$ analyzer of Thermo Scientific/Interscience. Analytical TLC was performed using Merck prepared plates (silica gel 60 F-254 on aluminium). Column chromatography was carried out on Merck silica gel 60 (230-400 mesh).

2,2'-Oxybis( $N, N$-bis(2-hydroxyethyl)acetamide) (2). To a solution of diethanolamine $(0.86 \mathrm{~g}, 8.2 \mathrm{mmol})$ in acetone (50 mL) containing $\mathrm{K}_{2} \mathrm{CO}_{3}(2.26 \mathrm{~g}, 16.4 \mathrm{mmol})$ was added diglycolyl dichloride (1) $(0.68 \mathrm{~g}, 3.9 \mathrm{mmol})$ dropwise at $0{ }^{\circ} \mathrm{C}$ and the resulting mixture was stirred overnight at room temperature, filtered and the solvent was evaporated. The residue was dissolved several times in $\mathrm{CHCl}_{3}(25 \mathrm{~mL})$ and decanted to remove the excess of diethanolamine to afford 2 $(0.85 \mathrm{~g}, 67 \%)$ as an oil. $\delta_{\mathrm{H}}\left(300 \mathrm{MHz} ; \mathrm{D}_{2} \mathrm{O}\right) 3.28$ and 3.36 $\left(4 \mathrm{H}, \mathrm{t}, J 6.0, \mathrm{NCH}_{2}\right), 3.56\left(8 \mathrm{H}, \mathrm{m}, \mathrm{CH}_{2} \mathrm{OH}\right), 4.29\left(4 \mathrm{H}, \mathrm{s}, \mathrm{OCH}_{2}\right)$; $\delta_{\mathrm{C}}\left(75 \mathrm{MHz} ; \mathrm{D}_{2} \mathrm{O}\right) 48.9,58.6,68.5,171.7 ; m / z 309.2(\mathrm{M}+\mathrm{H})^{+}$. HRMS 331.1418, calculated 331.1481 $(\mathrm{M}+\mathrm{Na})^{+}$.

2,2'-(((Benzylazanediyl)bis(ethane-2,1-diyl))bis(oxy))diethanol $(5 \mathbf{a})^{31}$. A mixture of 2-(2-chloroethoxy)ethanol (4a) $(2.00 \mathrm{~g}$, $16 \mathrm{mmol})$, benzylamine $(0.86 \mathrm{~g}, 8.0 \mathrm{mmol}), \mathrm{K}_{2} \mathrm{CO}_{3}(4 \mathrm{~g}$, $29 \mathrm{mmol})$, and KI $(2.5 \mathrm{~g})$ in DMF $(30 \mathrm{~mL})$ was heated at $110{ }^{\circ} \mathrm{C}$ overnight. The solvent was evaporated and the residue was dissolved in ethyl acetate $(50 \mathrm{~mL})$ and filtered. The filtrate was washed with $5 \% \mathrm{HCl}(2 \times 30 \mathrm{~mL})$ and water $(2 \times 30 \mathrm{~mL})$, dried over anhydrous $\mathrm{MgSO}_{4}$, and concentrated under reduced pressure to give $5 \mathbf{a}(2.0 \mathrm{~g}, 77 \%)$ as an oil. $\delta_{\mathrm{H}}\left(300 \mathrm{MHz} ; \mathrm{CDCl}_{3}\right)$ 2.76-2.86 (4H, m, N(CH $\left.)_{2}\right), 3.56$ and $3.64\left(4 \mathrm{H}, \mathrm{t}, J 6.0, \mathrm{OCH}_{2}\right)$, $3.70\left(4 \mathrm{H}, \mathrm{t}, J\right.$ 6.0, $\left.\mathrm{CH}_{2} \mathrm{OH}\right), 3.83\left(2 \mathrm{H}, \mathrm{s}, \mathrm{NCH}_{2} \mathrm{Ph}\right), 7.27-7.45$ $(5 \mathrm{H}, \mathrm{m}, \mathrm{ArH}) ; m / z 283.9(\mathrm{M}+\mathrm{H})^{+}$.

\section{9-Benzyl-3,6,12,15-tetraoxa-9-azaheptadecane-1,17-diol} (5b). Compound $\mathbf{5 b}$ was synthesized by a similar procedure as described for 5a. 2-(2-(2-Chloroethoxy)ethoxy)ethanol (4b)
(2.50 g, $14.4 \mathrm{mmol})$, benzylamine (0.82 g, $7.7 \mathrm{mmol}), \mathrm{K}_{2} \mathrm{CO}_{3}$ $(4 \mathrm{~g}, 29 \mathrm{mmol})$ and $\mathrm{KI}(2.5 \mathrm{~g})$ afforded $\mathbf{5 b}(2.14 \mathrm{~g}, 75 \%)$ as an oil. $\delta_{\mathrm{H}}\left(300 \mathrm{MHz} ; \mathrm{CDCl}_{3}\right) 2.90\left(4 \mathrm{H}, \mathrm{t}, J\right.$ 6.0, $\left.\mathrm{N}\left(\mathrm{CH}_{2}\right)_{2}\right)$, 3.50-3.84 (22H, m, $\mathrm{OCH}_{2}$ and $\left.\mathrm{NCH}_{2} \mathrm{Ph}\right), 7.20-7.36(5 \mathrm{H}, \mathrm{m}$, ArH). $\delta_{\mathrm{C}}\left(75 \mathrm{MHz} ; \mathrm{CDCl}_{3}\right) 50.7,56.1,57.9,66.2,67.0,69.5$, 122.2, 125.1, 126.0, 135.7; $m / z 372.2(\mathrm{M}+\mathrm{H})^{+}$. HRMS $m / z$ 372.2046, calculated 372.2386 .

\section{2,2'-((Azanediylbis(ethane-2,1-diyl))bis(oxy))diethanol}

(6a) ${ }^{\mathbf{3 2}}$. A solution of $\mathbf{5 a}(1.70 \mathrm{~g}, 6.0 \mathrm{mmol})$ in methanol $(30 \mathrm{~mL})$ in the presence of $10 \% \mathrm{Pd} / \mathrm{C}(0.5 \mathrm{~g})$ was kept under $\mathrm{a}_{2}$ atmosphere overnight. After removal of the catalyst by filtration the solvent was evaporated under reduced pressure to afford 6a $(1.03 \mathrm{~g}, 93 \%)$ as an oil. $\delta_{\mathrm{H}}\left(300 \mathrm{MHz} ; \mathrm{CDCl}_{3}\right)$ $2.83\left(4 \mathrm{H}, \mathrm{t}, J 6.0, \mathrm{~N}\left(\mathrm{CH}_{2}\right)_{2}\right), 3.56-3.63\left(8 \mathrm{H}, \mathrm{m}, \mathrm{OCH}_{2}\right), 3.71$ $\left(4 \mathrm{H}, \mathrm{t}, J 6.0, \mathrm{CH}_{2} \mathrm{OH}\right), 4.04(2 \mathrm{H}$, br s, OH $) ; m / z 194.1(\mathrm{M}+\mathrm{H})^{+}$.

3,6,12,15-Tetraoxa-9-azaheptadecane-1,17-diol (6b) ${ }^{33}$. Compound $\mathbf{6 b}$ was synthesized by a similar procedure as described for 6a. Starting from $\mathbf{5 b}(1.80 \mathrm{~g}, 4.8 \mathrm{mmol})$ and $10 \% \mathrm{Pd} / \mathrm{C}$ $(0.5 \mathrm{~g})$ gave $6 \mathbf{b}(1.18 \mathrm{~g}, 87 \%)$ as an oil. $\delta_{\mathrm{H}}\left(300 \mathrm{MHz} ; \mathrm{CDCl}_{3}\right)$ 2.89 (4H, t, J 6.0, N( $\left.\left.\mathrm{CH}_{2}\right)_{2}\right), 3.56-3.74\left(20 \mathrm{H}, \mathrm{m}, \mathrm{OCH}_{2}\right), 4.09$ $(2 \mathrm{H}$, br s, OH $) ; m / z 282.1(\mathrm{M}+\mathrm{H})^{+}$; HRMS 282.1928, calculated 282.1917 .

\section{2,2'-Oxybis( $N, N$-bis(2-(2-hydroxyethoxy)ethyl)acetamide)}

(7a). The same procedure was adopted as described for 2 . Starting from $\mathbf{6 a}(0.80 \mathrm{~g}, 4.1 \mathrm{mmol})$, diglycolyl dichloride (1) (0.35 g, $2.1 \mathrm{mmol})$, and $\mathrm{K}_{2} \mathrm{CO}_{3}(1.1 \mathrm{~g}, 8 \mathrm{mmol})$ afforded $7 \mathbf{a}$ $(0.61 \mathrm{~g}, 62 \%) . \quad \delta_{\mathrm{H}}\left(300 \mathrm{MHz} ; \mathrm{D}_{2} \mathrm{O}\right) 3.37(4 \mathrm{H}, \mathrm{t}, J 6.0$, $\left.\mathrm{CONCH}_{2}\right), 3.42-3.47\left(12 \mathrm{H}, \mathrm{m}, \mathrm{NCH}_{2}\right.$ and $\left.\mathrm{OCH}_{2}\right), 3.49-3.58$ $\left(16 \mathrm{H}, \mathrm{m}, \mathrm{CH}_{2} \mathrm{OH}\right), 4.31\left(4 \mathrm{H}, \mathrm{s}, \mathrm{OCH}_{2}\right) ; \delta_{\mathrm{C}}\left(75 \mathrm{MHz} ; \mathrm{D}_{2} \mathrm{O}\right)$ $60.6,67.8,68.1,68.5,71.8,72.2,171.7$; HRMS $m / z 485.2742$ $(\mathrm{M}+\mathrm{H})^{+}$, calculated 485.2710 .

2,2'-Oxybis( $N, N$-bis(2-(2-(2-hydroxyethoxy)ethoxy)ethyl)acetamide) (7b). The same procedure was adopted as described for the synthesis of 2. Starting from 7a $(0.90 \mathrm{~g}, 3.2 \mathrm{mmol})$, diglycolyl dichloride (1) $(0.27 \mathrm{~g}, 1.6 \mathrm{mmol})$, and $\mathrm{K}_{2} \mathrm{CO}_{3}(1.0 \mathrm{~g}$, $7.2 \mathrm{mmol})$ gave $7 \mathbf{b}(0.66 \mathrm{~g}, 63 \%) . \delta_{\mathrm{H}}\left(300 \mathrm{MHz} ; \mathrm{D}_{2} \mathrm{O}\right) 3.36(4 \mathrm{H}, \mathrm{t}$, $J$ 6.0, $\left.\mathrm{NCH}_{2}\right), 3.42-3.47\left(12 \mathrm{H}, \mathrm{m}, \mathrm{NCH}_{2}\right.$ and $\left.\mathrm{CH}_{2} \mathrm{OH}\right)$, 3.49-3.59 (32H, m, OCH $), 4.29\left(4 \mathrm{H}, \mathrm{s}, \mathrm{OCH}_{2}\right) ; \delta_{\mathrm{C}}(75$ $\mathrm{MHz}$; D 2 O) 60.5, 67.8, 68.1, 69.7, 70.2, 71.8, 171.5; HRMS $m / z 661.3782(\mathrm{M}+\mathrm{H})^{+}$, calculated 661.3759 .

Tetramethyl 2,2', $\mathbf{2}^{\prime \prime}, \mathbf{2}^{\prime \prime \prime}$-((2,2'-oxybis(acetyl))bis(azanetriyl))tetraacetate (9). To a solution of dimethyl 2,2'-azanediyldiacetate $(1.50 \mathrm{~g}, 9.3 \mathrm{mmol})$ in THF $(50 \mathrm{~mL})$, containing triethylamine $(1.0 \mathrm{~g}, 9.9 \mathrm{mmol})$ as a base was added diglycolyl dichloride (1) $(0.79 \mathrm{~g}, 4.6 \mathrm{mmol})$ in THF $(15 \mathrm{~mL})$ dropwise at $0{ }^{\circ} \mathrm{C}$. The mixture was stirred at room temperature overnight, whereupon the solvent was evaporated. The residue was dissolved in dichloromethane $(50 \mathrm{~mL})$, washed with $10 \% \mathrm{HCl}$ $(2 \times 40 \mathrm{~mL})$, sat. aq. $\mathrm{NaHCO}_{3}(2 \times 40 \mathrm{~mL})$, and water $(50 \mathrm{~mL})$ to afford $9(1.51 \mathrm{~g}, 80 \%)$ as an oil. $\delta_{\mathrm{H}}\left(300 \mathrm{MHz} ; \mathrm{CDCl}_{3}\right)$ 3.72 and $3.75(6 \mathrm{H}, \mathrm{s}, \mathrm{C}(\mathrm{O}) \mathrm{OMe}), 4.19$ and $4.21\left(4 \mathrm{H}, \mathrm{s}, \mathrm{NCH}_{2}\right)$, $4.27\left(4 \mathrm{H}, \mathrm{s}, \mathrm{OCH}_{2}\right) ; \delta_{\mathrm{C}}\left(75 \mathrm{MHz} ; \mathrm{CDCl}_{3}\right) 48.2,49.5,52.4,52.5$, $52.8,69.5,169.5$; HRMS $m / z 421.1495(\mathrm{M}+\mathrm{H})^{+}$, calculated 421.1458 . 
Sodium $2,2^{\prime}, 2^{\prime \prime}, 2^{\prime \prime \prime}-\left(\left(2,2^{\prime}\right.\right.$-oxybis(acetyl))bis(azanetriyl))tetraacetate (10). To a solution of $9(1.00 \mathrm{~g}, 2.4 \mathrm{mmol})$ in a mixture of $\mathrm{MeOH}$ : water $(8: 2)(50 \mathrm{~mL})$ was slowly added $\mathrm{NaOH}$ $(0.38 \mathrm{~g}, 9.5 \mathrm{mmol})$ and the mixture was stirred at room temperature for 2 days. The mixture was concentrated to dryness under reduced pressure to afford pure 10 (1.07 g, quant.) as a white solid. Mp 284-286 ${ }^{\circ} \mathrm{C} . \delta_{\mathrm{H}}\left(300 \mathrm{MHz} ; \mathrm{D}_{2} \mathrm{O}\right)$ 3.67 and $3.74\left(4 \mathrm{H}, \mathrm{s}, \mathrm{NCH}_{2}\right), 4.18\left(4 \mathrm{H}, \mathrm{s}, \mathrm{OCH}_{2}\right) ; \delta_{\mathrm{C}}(75 \mathrm{MHz}$; $\left.\mathrm{D}_{2} \mathrm{O}\right)$ 51.6, 68.4, 171.3, 175.7, 176.4; HRMS $m / z 453.0160$ $(\mathrm{M}+\mathrm{H})^{+}$, calculated 453.0110 .

$O, O, O^{\prime}, O^{\prime}$-Tetraethyl(oxybis(methylene))diphosphonothioate (13). To a solution of diethyl(hydroxymethyl)phosphonate $(0.73 \mathrm{~g}, 4.3 \mathrm{mmol})$ in THF $(40 \mathrm{~mL})$ was slowly added $\mathrm{NaH}$ at $0{ }^{\circ} \mathrm{C}$ portion wise. After stirring at this temperature for $1 \mathrm{~h}$, a solution of (diethoxyphosphoryl)methyl trifluoromethanesulfonate (11) $(1.30 \mathrm{~g}, 4.3 \mathrm{mmol})$ in THF $(15 \mathrm{~mL})$ was added and stirring was continued overnight at room temperature. The solvent was evaporated under reduced pressure and the residue was dissolved in chloroform $(30 \mathrm{~mL})$. The resulting solution was washed with $10 \% \mathrm{HCl}(3 \times 50 \mathrm{~mL})$ and water $(3 \times 50 \mathrm{~mL})$. The organic layer was dried over anhydrous $\mathrm{MgSO}_{4}$ and concentrated under reduced pressure, followed by purification of the residue with chromatography $\left(\mathrm{SiO}_{2}\right.$, dichloromethane) to afford $12(1.02 \mathrm{~g}, 74 \%)$ as an oil. $\delta_{\mathrm{H}}\left(300 \mathrm{MHz} ; \mathrm{CDCl}_{3} ; \mathrm{Me}_{4} \mathrm{Si}\right) 1.32$ $\left(12 \mathrm{H}, \mathrm{t}, J 7.0, \mathrm{CH}_{3}\right), 3.85\left(4 \mathrm{H}, \mathrm{d}, J 6.0, \mathrm{OCH}_{2} \mathrm{P}\right), 4.16(8 \mathrm{H}$, pentet, $\left.J 7.0, \mathrm{OCH}_{2}\right) \cdot{ }^{34}$ A solution of $12(1.00 \mathrm{~g}, 3.1 \mathrm{mmol})$ and Lawesson's reagent $(2.54 \mathrm{~g}, 6.2 \mathrm{mmol})$ was refluxed in toluene for $2 \mathrm{~h}$. After removal of the solvent the residue was separated by chromatography $\left(\mathrm{SiO}_{2}\right.$, dichloromethane) to afford 13 $(0.87 \mathrm{~g}, 80 \%)$ as an oil. $\delta_{\mathrm{H}}\left(300 \mathrm{MHz}, \mathrm{CDCl}_{3}\right) 1.33(12 \mathrm{H}, \mathrm{t}$, $J$ 7.0, $\left.\mathrm{CH}_{3}\right), 4.10\left(4 \mathrm{H}, \mathrm{d}, J 3.0, \mathrm{OCH}_{2} \mathrm{P}\right), 4.12-4.25(8 \mathrm{H}, \mathrm{m}$, $\left.\mathrm{OCH}_{2}\right) ; \delta_{\mathrm{C}}\left(75 \mathrm{MHz} ; \mathrm{CDCl}_{3}\right) 16.5,63.3,72.5,74.2 ; \mathrm{HRMS} m / z$ $351.0631(\mathrm{M}+\mathrm{H})^{+}$, calculated 351.0619 .

(Oxybis(methylene))diphosphonic acid (14). A suspension of $13(0.90 \mathrm{~g}, 2.5 \mathrm{mmol})$ in conc. $\mathrm{HCl}(20 \mathrm{~mL})$ was heated in a sealed tube at $100{ }^{\circ} \mathrm{C}$ overnight. The $\mathrm{HCl}$ was evaporated under reduced pressure. The residue was dissolved in water $(25 \mathrm{~mL})$, and the solution was extracted with chloroform $(2 \times$ $25 \mathrm{~mL}$ ) to remove non-water soluble impurities. Removal of the solvent under reduced pressure gave $14(0.46 \mathrm{~g}, 70 \%)$ as a dense oil. $\delta_{\mathrm{H}}\left(300 \mathrm{MHz} ; \mathrm{D}_{2} \mathrm{O}\right) 3.62\left(4 \mathrm{H}, \mathrm{d}, J\right.$ 9.0, $\left.\mathrm{OCH}_{2}\right)$; $\delta_{\mathrm{C}}\left(75 \mathrm{MHz} ; \mathrm{D}_{2} \mathrm{O}\right) 66.9,69.1 ; m / z 207.0(\mathrm{M}+\mathrm{H})^{+}$; HRMS $m / z 206.9833(\mathrm{M}+\mathrm{H})^{+}$, calculated 206.9824.

Methylenediphosphonothioic dichloride (16). A mixture of thiophosphoryl chloride (15 mL) and bis(dichlorophosphino)methane $(1.00 \mathrm{~g}, 4.5 \mathrm{mmol})$ was refluxed for $5 \mathrm{~h}$ at $115^{\circ} \mathrm{C}$. The excess of $\mathrm{PSCl}_{3}$ was evaporated under reduced pressure to afford 16 (1.3 g, quant.). $\delta_{\mathrm{H}}\left(300 \mathrm{MHz} ; \mathrm{CDCl}_{3}\right) 4.48(4 \mathrm{H}, \mathrm{t}$, $\left.J 15.0, \mathrm{PSCH}_{2} \mathrm{PS}\right)$. In the $\mathrm{ESI}^{+}$mass spectrum a characteristic pattern was observed at $m / z$ 278.8, 281.8, 283.8, 285.8 for $[\mathrm{M}+\mathrm{H}]^{+}$that corresponds to the calculated isotopic abundance of four chlorides.

Methylenediphosphonothioic $\boldsymbol{O}, \boldsymbol{O}$-acid (17). A mixture of $\mathbf{1 6}$ $(1.00 \mathrm{~g}, 3.5 \mathrm{mmol})$ in acetone: water $(1: 1)(50 \mathrm{~mL})$ was stirred at room temperature for $1 \mathrm{~h}$. The solvent was evaporated to give pure $17(0.70 \mathrm{~g}$, quant.) as a solid (found $\mathrm{C}, 5.95 ; \mathrm{H}, 2.65$.
$\mathrm{CH}_{6} \mathrm{O}_{4} \mathrm{P}_{2} \mathrm{~S}_{2}$ requires $\left.\mathrm{C}, 5.8 ; \mathrm{H}, 2.9 \%\right)$. Mp 131-133 ${ }^{\circ} \mathrm{C}$; $\delta_{\mathrm{H}}\left(300 \mathrm{MHz} ; \mathrm{CD}_{3} \mathrm{C}(\mathrm{O}) \mathrm{CD}_{3}\right) 2.99\left(2 \mathrm{H}, \mathrm{t}, J 16.5, \mathrm{PSCH}_{2} \mathrm{PS}\right)$, $7.02\left(4 \mathrm{H}\right.$, br s, OH); $\delta_{\mathrm{C}}\left(75 \mathrm{MHz} ; \mathrm{D}_{2} \mathrm{O}\right)$ 57.7; HRMS $m / z$ $208.9297(\mathrm{M}+\mathrm{H})^{+}$, calculated 208.9261.

2,2'-(Benzylazanediyl)bis( $N, N$-dimethylacetamide) (19). A mixture of 2-chloro- $N, N$-dimethylacetamide (18) $(2.30 \mathrm{~g}$, $18.9 \mathrm{mmol})$, benzylamine $(1.00 \mathrm{~g}, 9.5 \mathrm{mmol}), \mathrm{K}_{2} \mathrm{CO}_{3}(5.2 \mathrm{~g}$, $38 \mathrm{mmol})$ and $\mathrm{KI}(3 \mathrm{~g})$ in acetonitrile $(50 \mathrm{~mL})$ was refluxed for $6 \mathrm{~h}$. The acetonitrile was evaporated and the residue was dissolved in ethyl acetate $(50 \mathrm{~mL})$. The resulting solution was washed with dil. $\mathrm{HCl}(3 \times 50 \mathrm{~mL})$ and water $(3 \times 50 \mathrm{~mL})$. The organic layer was dried over anhydrous $\mathrm{MgSO}_{4}$ and concentrated under reduced pressure. The residue was purified by chromatography $\left(\mathrm{SiO}_{2}, \mathrm{EtOAc}\right)$ to afford 21 (4.20 g, 81\%) as an oil. $\delta_{\mathrm{H}}\left(300 \mathrm{MHz} ; \mathrm{CDCl}_{3}\right) 2.91$ and $2.95\left(6 \mathrm{H}, \mathrm{s}, \mathrm{NMe}_{2}\right), 3.74$ $\left(4 \mathrm{H}, \mathrm{s}, \mathrm{NCH}_{2}\right), 4.02\left(2 \mathrm{H}, \mathrm{s}, \mathrm{NCH}_{2} \mathrm{Ph}\right) ; \delta_{\mathrm{C}}\left(75 \mathrm{MHz} ; \mathrm{CDCl}_{3}\right)$ 35.6, 36.9 , 55.6, 59.1, 127.5, 128.5, 129.4, 138.3, 170.3; HRMS $m / z$ $278.1875(\mathrm{M}+\mathrm{H})^{+}$, calculated 278.1869 .

2,2'-Azanediylbis $(N, N$-dimethylacetamide) (20). A mixture of $19(1.20 \mathrm{~g}, 4.3 \mathrm{mmol})$ and $10 \% \mathrm{Pd} / \mathrm{C}(0.5 \mathrm{~g})$ in ethanol (40 mL) was kept under a $\mathrm{H}_{2}$ atmosphere overnight. After removal of the catalyst by filtration, the solvent was evaporated under reduced pressure to afford $20(0.80 \mathrm{~g}$, quant.) as a solid (found $\mathrm{C}, 51.3 ; \mathrm{H}, 9.0 ; \mathrm{N}, 22.6 . \mathrm{C}_{8} \mathrm{H}_{17} \mathrm{~N}_{3} \mathrm{O}_{2}$ requires $\mathrm{C}$, $51.3 ; \mathrm{H}, 9.15 ; \mathrm{N}, 22.4 \%) . \mathrm{Mp} 58-60{ }^{\circ} \mathrm{C} . \delta_{\mathrm{H}}\left(300 \mathrm{MHz} ; \mathrm{CDCl}_{3}\right)$ 2.98 and $3.02\left(6 \mathrm{H}, \mathrm{s}, \mathrm{NMe}_{2}\right), 4.22\left(4 \mathrm{H}, \mathrm{s}, \mathrm{NCH}_{2}\right) ; \delta_{\mathrm{C}}(75 \mathrm{MHz}$; $\left.\mathrm{CDCl}_{3}\right)$ 35.6, 36,3, 50.1, 170.5; HRMS $m / z 188.1411(\mathrm{M}+\mathrm{H})^{+}$, calculated 188.1399 .

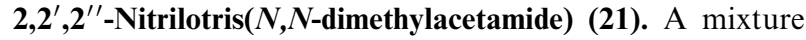
of $20(0.70 \mathrm{~g}, 3.7 \mathrm{mmol}), 2$-chloro- $N, N$-dimethylacetamide (18) (0.45 g, $3.7 \mathrm{mmol}), \mathrm{K}_{2} \mathrm{CO}_{3}(1 \mathrm{~g}, 7.4 \mathrm{mmol})$, and $\mathrm{KI}(0.5 \mathrm{~g})$ in acetonitrile $(30 \mathrm{~mL})$ was refluxed overnight. The acetonitrile was evaporated and the residue dissolved in ethyl acetate $(50 \mathrm{~mL})$. The resulting solution was filtered and the solvent evaporated. The residue was dissolved in water $(50 \mathrm{~mL})$ and the solution was extracted with dichloromethane $(3 \times 50 \mathrm{~mL})$. Removal of the water afforded pure $21(0.74 \mathrm{~g}, 75 \%)$ as an oil. $\delta_{\mathrm{H}}\left(300 \mathrm{MHz} ; \mathrm{CDCl}_{3}\right) 2.92$ and $3.04\left(18 \mathrm{H}, \mathrm{s}, \mathrm{NMe}_{2}\right), 3.62(6 \mathrm{H}$, s, $\left.\mathrm{NCH}_{2}\right) ; \delta_{\mathrm{C}}\left(75 \mathrm{MHz} ; \mathrm{CDCl}_{3}\right)$ 35.6, 37.2, 55.9, 60.1, 169.8; HRMS $m / z 295.1741(\mathrm{M}+\mathrm{Na})^{+}$calculated 295.1746.

2,2' $\mathbf{2}^{\prime \prime}$-Nitrilotris( $N, N$-bis(2-hydroxyethyl)acetamide) (23). A mixture of triester $22(2.00 \mathrm{~g}, 8.5 \mathrm{mmol})$ and diethanolamine $(2.70 \mathrm{~g}, 25.7 \mathrm{mmol})$ was heated as neat at $120{ }^{\circ} \mathrm{C}$ for $5 \mathrm{~h}$ to give $23(3.14 \mathrm{~g}, 81 \%)$ as an oil. $\delta_{\mathrm{H}}\left(300 \mathrm{MHz} ; \mathrm{D}_{2} \mathrm{O} ; \mathrm{Me}_{4} \mathrm{Si}\right) 3.31$ and $3.39\left(6 \mathrm{H}, \mathrm{t}, J\right.$ 6.0, $\left.\mathrm{CONCH}_{2}\right), 3.51-4.01\left(18 \mathrm{H}, \mathrm{m}, \mathrm{NCH}_{2}\right.$ and $\left.\mathrm{CH}_{2} \mathrm{OH}\right) ; \delta_{\mathrm{C}}\left(75 \mathrm{MHz} ; \mathrm{D}_{2} \mathrm{O}\right) ; 48.1,50.1$, 55.6, 58.9, 173.0; HRMS $m / z 453.2618(\mathrm{M}+\mathrm{H})^{+}$, calculated 453.2561.

\section{Microcalorimetry experiments}

Calorimetric measurements were carried out in water at $\mathrm{pH} 3$ and $25{ }^{\circ} \mathrm{C}$ using a Microcal VP-ITC microcalorimeter with a cell volume of $1.4115 \mathrm{~mL}$. The $\mathrm{pH}$ of the solution was adjusted by $65 \% \mathrm{HNO}_{3}$. For studying the complexation of $\mathrm{Eu}(\mathrm{III})$ to the ligands $\mathbf{2}, \mathbf{7 a}, \mathbf{7 b}, \mathbf{2 1}$, and $\mathbf{2 3}$, aliquots of a $10.0 \mathrm{mM}$ aqueous solution of the ligands in the buret were added to a $0.166 \mathrm{mM}$ solution of $\mathrm{Eu}\left(\mathrm{NO}_{3}\right)_{3}$ in the calorimetric cell, 
monitoring the heat change after each addition. Dilution experiments showed that at the experimental concentrations none of the species described above showed significant aggregation behavior.

\section{Extraction procedure}

All the aqueous solutions were prepared by dissolution of weighted amounts of the ligand in ultrapure water (resistivity, $18 \mathrm{M} \Omega \mathrm{cm}^{-1}$ ) containing $0.5 \mathrm{~mol} \mathrm{~L}^{-1} \mathrm{NH}_{4} \mathrm{NO}_{3}$ (salting-out agent). The initial $\mathrm{pH}_{\text {ini }}$ of the aqueous phase was adjusted using ammonia or diluted nitric acid. The organic solvent consisted of $0.2 \mathrm{~mol} \mathrm{~L}^{-1}$ TODGA (extractant) and $5 \mathrm{vol} \%$ 1 -octanol dissolved in TPH.

The organic phase was not loaded with Am and Eu followed by stripping as TODGA extracts significant amounts of $\mathrm{HNO}_{3}$ which would prevent obtaining reasonable results at $\mathrm{pH}>1$ without using a buffer. Instead each of the aqueous phases $(500 \mu \mathrm{L})$ were spiked with $10 \mu \mathrm{L}$ of radiotracer $\left({ }^{241} \mathrm{Am},{ }^{152} \mathrm{Eu}\right.$, approx. $25 \mathrm{KBq} \mathrm{mL}^{-1}$ ) and contacted with the organic solvent $\left(500 \mu \mathrm{L}\right.$ ) by shaking for $60 \mathrm{~min}$ at $22{ }^{\circ} \mathrm{C} \pm 1{ }^{\circ} \mathrm{C}$ using an IKA Vibrax Orbital Shaker Model VXR (2,200 rpm). After phase separation by centrifugation, $200 \mu \mathrm{L}$ aliquots of each phase were withdrawn for radio analysis. The kinetics extraction experiments were performed similarly as described above, except the phases contact time (mixing time). Activity measurements of the $\gamma$-ray emitters were performed with a HPGe spectrometer, EG-G Ortec using the $\gamma$-lines at $59.5 \mathrm{keV}$, and $121.8 \mathrm{keV}$ for ${ }^{241} \mathrm{Am}$ and ${ }^{152} \mathrm{Eu}$, respectively. The distribution ratio $D_{\mathrm{M}}$ was measured as the ratio between the radioactivity in the organic and the aqueous phase (eqn (1)). Distribution ratios between 0.01 and 100 exhibit a maximum error of $\pm 5 \%$. The error may be up to $\pm 20 \%$ for smaller and larger values. The acidities of the initial and final aqueous solutions were determined using a 691 Metrohm pH meter $\left(3 \mathrm{~mol} \mathrm{~L}^{-1} \mathrm{KCl}\right)$.

\section{Acknowledgements}

The authors gratefully acknowledge the financial support from the EU ACSEPT (Actinide reCycling by SEParation and Transmutation) project (FP7 collaborative project 211267) and HEC (higher education commission) Pakistan.

\section{Notes and references}

1 Actinide and Fission Product Partitioning and TransmutationStatus and Assessment Report, OECD-NEA, Paris, France, 1999.

2 B. A. Moyer, Ion Exchange and Solvent Extraction: A Series of Advances, 2009, vol 19.

3 C. Musikas, Proceedings of Symposium on Americium and Curium Chemistry and Technology; International Chemical Congress of Pacific Basin Societies, Honolulu, 1985.

4 Y. Zhu, Radiochim. Acta, 1995, 68, 95.
5 Z. Kolarik, Chem. Rev., 2008, 108, 4208.

6 H. H. Dam, D. N. Reinhoudt and W. Verboom, Chem. Soc. Rev., 2007, 36, 367.

7 See: www.acsept.org.

8 Y. Sasaki and S. Tachimori, Solvent Extr. Ion Exch., 2002, 20, 21.

9 Y. Sasaki, Y. Sugo, S. Suzuki and S. Tachimori, Solvent Extr. Ion Exch., 2001, 19, 91.

10 Y. Sasaki and G. R. Choppin, Anal. Sci., 1996, 12, 225.

11 A. Facchini, L. Amato and R. Nannicini, Sep. Sci. Technol., 1996, 31, 2245.

12 P. R. Danesi, C. Cianetti and E. P. Horwitz, Sep. Sci. Technol., 1982, 17, 507.

13 Y. Sasaki, Y. Sugo, Y. Kitatsuji, A. Kirishima, T. Kimura and G. R. Choppin, Anal. Sci., 2007, 23, 727.

14 Y. Sasaki, H. Suzuki, Y. Sugo, T. Kimura and G. R. Choppin, Chem. Lett., 2006, 35, 256.

15 M. Heitzmann, F. Bravard, C. Gateau, N. Boubals, C. Berthon, J. Pécaut, M. C. Charbonnel and P. Delangle, Inorg. Chem., 2009, 48, 246.

16 M. Heitzmann, C. Gateau, L. Chareyre, M. Miguirditchian, M. C. Charbonnel and P. Delangle, New J. Chem., 2010, 34, 108.

17 L. Spjuth, J. O. Liljenzin, M. J. Hudson, M. G. B. Drew, P. B. Iveson and C. Madic, Solvent Extr. Ion Exch., 2000, 18, 1.

18 M. Iqbal, J. Huskens, W. Verboom, M. Sypula and G. Modolo, Supramol. Chem., 2010, 22, 827.

19 J. S. Bradshaw, H. An, K. E. Krakowiak, T. Wang, C. Zhu and R. M. Izatt, J. Org. Chem., 1992, 57, 6112.

20 In a second attempt diglycolic acid was reacted with diethanolamine in THF using DCC as a coupling reagent, however, no reaction occurred.

21 Reaction of $N$-benzyl protected diethanolamine with 2-bromoethanol in the presence of $\mathrm{NaH}$ as a base was not successful.

22 Y. Xu, M. T. Flavin and Z. Q. Xu, J. Org. Chem., 1996, 61, 7697.

23 M. Fild and W. Handke, Z. Anorg. Allg. Chem., 1987, 555, 109.

24 S. Nave, G. Modolo, C. Madic and F. Testard, Solvent Extr. Ion Exch., 2004, 22, 527.

25 T. Yaita, A. W. Herlinger, P. Thiyagarajan and M. P. Jensen, Solvent Extr. Ion Exch., 2004, 22, 553.

26 L. Rao, P. L. Zanonato, P. D. Bernardo and A. Bismondo, J. Chem. Soc., Dalton Trans., 2001, 1939.

27 Endothermic lanthanide complexes are well known in the literature: (a) L. Rao, P. L. Zanonato, P. D. Bernardo and A. Bismondo, Inorg. Chim. Acta, 2000, 306, 49; (b) R. G. de Carvalho and G. R. Choppin, J. Inorg. Nucl.Chem., 1967, 29, 737.

28 C. Louis, D. M. Christine, P. Claude and T. Pierre, Tetrahedron Lett., 1989, 30, 1369.

29 J. R. Green, M. Majewski and V. Snieckus, Can. J. Chem., 2006, 84, 1397.

30 L. H. Wei, Y. B. He, J. L. Wu, H. J. Qin, K. X. Xu and L. Z. Meng, Chin. J. Chem., 2005, 23, 609.

31 For another synthetic method see: N. G. Luk'yanenko, A. V. Lobach, N. Yu. Nazarova, L. P. Karpenko and L. N. Lyamtseva, Khim. Geterotsikl. Soedin., 1988, 687.

32 For another synthetic method see: A. V. Bordunov, P. C. Hellier, J. S. Bradshaw, N. K. Dalley, X. Kou, X. X. Zhang and R. M. Izatt, J. Org. Chem., 1995, 60, 6097.

33 For another synthetic method see: H. Maeda, S. Furuyoshi, Y. Nakatsuji and M. Okahara, Tetrahedron, 1982, 38, 3359.

34 For a related synthesis and more spectral data see: A. R. P. M. Valentijn, O. van den Berg, G. A. van der Marel, L. H. Cohen and J. H. van Boom, Tetrahedron, 1995, 51, 2099. 